\title{
Proceeding
}

Supplementary Issue: Winter Conferences of Sports Science. Costa Blanca Sports Science Events, 22-23 March 2021. Alicante, Spain.

\section{Development of sportsman students' autonomy in the educational environment of electronic information and foreign language teachers' readiness to this process}

\author{
OXANA E. CHERNOVA $1 \square$, ALEKSANDR V. LITVINOV2,3, LARISA N. GORBUNOVA ${ }^{4}$, IRINA V. \\ TELEZHKO5, SVETLANA M. NIZAMUTDINOVA 6 \\ 'Department of Foreign Languages, Academy of Engineering, Peoples' Friendship University of Russia (RUDN University), \\ Moscow, Russian Federation \\ ${ }^{2}$ Department of Foreign Languages, Faculty of Economics, Peoples' Friendship University of Russia (RUDN University), Moscow, \\ Russian Federation \\ ${ }^{3}$ Department of Foreign and Russian Philology, Moscow State University of Psychology and Education (MSUPE) Moscow, Russian \\ Federation \\ ${ }^{4}$ Department of Psychology and Pedagogy, Moscow Economic Institute, Private Educational Establishment of Higher Education, \\ Moscow Economic Institute, Moscow, Russian Federation \\ ${ }^{5}$ Department of Russian Language, Medical Institute, Peoples' Friendship University of Russia (RUDN University), Moscow, \\ Russian Federation \\ ${ }^{6}$ Department of Music, Moscow City University, Moscow, Russian Federation
}

\begin{abstract}
The study addresses the major factors preventing foreign language $(\mathrm{FL})$ teachers from effective use of electronic information educational environment (EIEE) at the institutes of higher learning $(\mathrm{IHL})$ in Russia to develop learner autonomy. Upon holding interviews and taking polls of 60 respondents from three universities helped the authors find out that these factors include: sketchy knowledge of information and communication technologies among foreign language teachers; poor standards of material and technical resources capability at universities; inadequate readiness of FL teachers to apply new information and communication technologies; insufficient level of FL teachers motivation to use innovative ITs at work. The contributors have worked out a number of pedagogical conditions that should be provided at the $\mathrm{IHL}$ to clear the barriers mentioned above: gradual development of $\mathrm{FL}$ teachers readiness to use the EIEE (the IT competence acquisition based on learning management systems (LMS); FL teachers activity stimulation to work in the EIEE through creating modular courses); setting up the EIEE in the IHL, which can translate all e-learning possibilities into action, the LMS, software and documentation among them. The said pedagogical conditions have successfully been tested and implemented at RUDN University.

Keywords: Sport activities; Learner autonomy; ESP students; Motivation; Life-long learning; Country-specific features.
\end{abstract}

\section{Cite this article as:}

Chernova, O.E., Litvinov, A.V., Gorbunova, L.N., Telezhko, I.V., \& Nizamutdinova, S.M. (2021). Development of sportsman students' autonomy in the educational environment of electronic information and foreign language teachers' readiness to this process. Journal of Human Sport and Exercise, 16(3proc), S1227-S1243. https://doi.org/10.14198//hse.2021.16.Proc3.39

Corresponding author. Department of Foreign Languages, Academy of Engineering, Peoples' Friendship University of Russia (RUDN University), Moscow, Russian Federation.

E-mail: oxana-c@mail.ru

Abstract submitted to: Winter Conferences of Sports Science. Costa Blanca Sports Science Events, 22-23 March 2021. Alicante, Spain.

JOURNAL OF HUMAN SPORT \& EXERCISE ISSN 1988-5202.

(c) Faculty of Education. University of Alicante.

doi:10.14198/jhse.2021.16.Proc3.39 


\section{INTRODUCTION}

This study takes on particular importance in Russia's educational policy of the 21 st century as the adoption of the life-long learning paradigm along with the brisk pace of development in various fields of the Russian society have led to a sea change in the system of higher education and introduction of the new requirements to the graduates of IHLs as autonomous individuals (Chernova et al., 2019).

The State Standards of Higher Education of the Russian Federation stipulate developing graduates competencies that follow: the ability to find, sort out, interpret, analyse, make a synthesis and use of the information obtained; the skill to set goals and assign tasks independently and make a choice of the best possible solution; to the art of working out a self-development path for life; time-management, - the skills that are an intrinsic part of the learner autonomy (Shinkevich et al., 2020).

In the current climate, however, the level of autonomy development among the Russian universities graduates is at odds with the abovementioned requirements. With more and more employers complaining about the spoon-fed nature of graduates, there is a real need to make sure that students graduate from universities with the necessary set of skills to succeed in the 21 st century as responsible and critical members of the communities they live in, as well as independent and free-thinking global citizens. In this context, one of the priorities is the introduction of new teaching techniques and methods for the development of learner autonomy, review of traditional approaches to the learning process, creation and implementation of electronic information educational environment (EIEE) at the IHL, which comprises electronic educational resources in a learning management system (LMS). In the 21 st century it is the EIEE that will promote higher standards of $\mathrm{IHL}$ training on the basis of individualization and intensification of the educational process with the view of developing learner ability to continue self-improvement; creating new opportunities for both personal and professional growth; setting up novel environment for promoting students motivation, giving rise to a new attitude towards the subjects being taught (Goloshumova \& Chernova, 2017); fostering skills of productive learning self-organization. For instance, Peoples' Friendship University of Russia (RUDN University), among quite a few highly-rated universities in the world, applied the LMS MOODLE to create EIEE, which let make use of the students individual learning style, provide tutorials, employ different pedagogical approaches and a wide range of tools to design a course consisting of both standard and optional modules, etc. (Chernova et al., 2019).

Professors' role in developing students' autonomy is quite significant. The former do have to be motivated, open-minded and focused on achieving the goal set. They also have to be acquainted with modern ITs and use them efficiently in their work, as well as develop their competences in this field. University professors are expected to perform in tune with the times and stringent requirements, and, hence, have to face emerging challenges and acquire yet another knowledge and various skills. Besides, in all their teaching activities professors are supposed to be able to apply their professional skills independently (Goloshumova et al., 2017). So, as teachers we need to encourage autonomy within the classroom, to help learners become independent so that they could deal with learning on their own, to equip them with the necessary skills and various strategies to learn a FL independently, to let go and give students both the power and the control to learn in a more independent, autonomous fashion. In the modern world it is a 21 st century skill that that has to be a must for graduating (Efimova et al., 2019; Erofeeva et al., 2019b; Kalinina, 2011; Telysheva et al., 2019).

Today teaching in the IHL involves quite a number of different activities, among them are the following: instructing students, learning new information, mastering novel skills, being up to date with constantly 
emerging technological innovations, dealing with students and the society. In some communities, dominated primarily by the individualist culture, e.g., the USA, it is easier to develop learner autonomy, while in others, focused on groups, teams, e.g., Russia, it might be harder, but still possible (Erofeeva et al., 2019c; Lekareva et al., 2018; Romanova et al., 2019; Kayumova et al., 2020).

\section{METHODOLOGICAL FRAMEWORK}

\section{Learner autonomy}

Since the beginning of the 1970's when the word autonomy came into use in language learning, various scholars have put forward quite a number of its definitions. It is worth mentioning that defining autonomy can be considered a challenge because of its broad and abstract nature.

In H. Holec's (1979) point of view, autonomy can be considered as an ability to be responsible for one's own learning'.

D. Nunan (2000) states that learners can be described as autonomous if they can independently determine the direction of their educational process, take an active part in the control of this process, have a freedom of choice regarding resources to be used and scope of activity.

According to P. Benson (2001), learner autonomy is a capacity to control students own learning, mainly since the concept of 'control' is easier to investigate than that of 'charge' or 'responsibility'.

P. Ur (1996) regards autonomy as one of the three stages in the process of learning a skill: verbalization, automation and autonomy. At the last stage learners continue to use the skill on their own, becoming proficient and creative. That means that the learners have become autonomous'.

D. Little (1995) states that learner autonomy results from interdependence as opposed to independence.

W. Littlewood (1999) introduces two levels of autonomy: 'proactive autonomy' and 'reactive autonomy'. The former means control of both the activity direction and the activity itself. The latter regulates the activity after outlining the direction, it allows students to arrange their resources independently for the objective to be achieved, and it stimulates the learner to do their learning.

N. Aoki (2008) defines autonomy as the capacity to control one's own learning, to select and plan what and how one is going to learn and evaluate the effect of the learning when he or she desires to learn something.

Umeda (2004) considers that autonomous learning means not only studying alone or selecting, deciding, and planning all by oneself, but also having the capacity to ask others for assistance and making good use of other resources is crucial in order to select and plan the learner's own learning.

Russian researchers in this area of study have their own views of learner autonomy and, hence, of its definitions. In Y.N. Kulutkin's (1985) view, learner autonomy has both outer (learning strategies and activities) and inner (self-regulation) manifestations. Learners are both the subject and the object of control, and to some degree they become teachers.

The Russian-English terminological reference book edited by I.A. Kolesnikova (2003) defines autonomous learning as complete independence, self-sufficiency of learners, when the teacher is almost excluded from 
the educational process and it is the student who determines objectives of learning, the courses of study and materials.

Russian researchers, who work at the concept of learner autonomy in foreign language teaching, use the following terms:

- Self-guided learning of foreign languages. A.E. Kapaeva (2001) defines it as an independent learning activity, induced by learning-cognitive motivation. According to T.Y. Tambovkina (2007), it is a specific sort of cognitive activity aimed at autonomous learning of a foreign language by means of independent development of the foreign language self-teaching competence and building up one's own model of selfteaching on the basis of acquired language skills.

- Independent learning activity. K.V. Simonyan (2008) defines it as 'a learning activity characterized by the learner independence, their diligence, development of specific skills of learning organization combined with the learner ability to commence their learning activities, capability to control these activities, which will promote cognitive self-dependence, controlled, assessed and managed by means of computer-aided technologies.

- Learner self-regulation (Anikina, 2011; N.F. Koryakovtseva; Luksha, 2008; Nasonova, 2008; E.N. Solovova; Ternovykh, 2007). According to I.V. Luksha (2008), the term means students awareness of their responsibility for the process and the result of their learning activities. E.A. Nasonova (2008) considers that learner self-regulation means students desire and ability to be a responsible member of the educational process, to realize their learning activities and be engaged in self-development in learning and professional aspects. From the N.F. Koryakovtseva (2001) point of view, the term means a learner ability to perform one's learning activity independently, to take an active stand and conscious control of this activity, to self-reflect and make corrections, to accumulate one's own experience, to make independent decisions regarding one's learning process in various educational environments. T.Y. Ternovykh (2007) is committed to applying the term in its proper sense that means students intensive control of their learning process and responsibility for it. According to Zh. S. Anikina (2011), learner self-regulation is a learner ability to set goals independently, to plan one's activity, to choose methods of learner activities and types of work, while also to self-reflect, selfcontrol, and self-correct and be fully responsible for the results of their learning activity and to transfer these results into a new learning environment.

- Learner autonomy (Khodyakov, 2013; Tsvetkova, 2001; Tsyvkunova, 2002). E.A. Tsyvkunova (2002) defines learner autonomy as 'an ability, desire and readiness of the student to self-learn, to take a responsibility for his/her learning efficiency during their university studies, to acquire skills that will allow to self-study and self-improve after the graduation of the university. According to T.K. Tsvetkova (2001), learner autonomy is one's ability to acquire new expertise and perfect foreign language skills independently. D.A. Khodyakov (2013) believes that "learner autonomy is an integrative quality of individuals assuming the willingness to independently regulate their learning activities in accordance with his/her needs and abilities, together with the teacher or independently, selecting the goals, content and methods of teaching and evaluating the results".

The learner autonomy definitions analysis results can be divided into three groups: 1) autonomy is the learner ability (Holec, 1979; Little, 1991; Benson, 2001; Koryakovtseva, 2001; I.D. Trofimova; Tambovkina, 2007); 2) autonomy is not an ability or a necessity, it is rather a learner's responsibility (L. Dickinson, E.N. Solovova);

3) autonomy as willingness to manage one's own learning process (Khodyakov, 2013). 
We agree with those scholars who believe that learner autonomy is an ability and by this ability we mean an individually expressed trait of a person which enables him/her to carry out specific activities.

It should also be noted that in methodology of teaching foreign languages there is no consensus on terminology to denote this concept: according to N.F. Koryakovtseva (2001) and T.Y. Ternovykh (2007), the terms "learner self-regulation" and "learner autonomy" are synonymous. T.Y. Tambovkina (2007), I.D. Trofimova, Zh.S. Anikina (2011) prefer the term "learner self-regulation", E.A. Tsyvkunova (2002), T.K. Tsvetkova (2001) opt for "learner autonomy", whereas E.V. Apanovich (2003) and N.D. Galskova consider the concepts of "independent" and "autonomous" to be alike and interchangeable.

The authors of this article fully agree with those scholars (E.N. Solovova, K.E. Bezukladnikov) who believe that learner autonomy cannot be equated with an independent learning activity.

The definitions of learner autonomy formulated by Russian and Western scholars reveal a high degree of alikeness. Most scientists by learner autonomy understand an ability for self-reflection, taking responsibility for the results of the educational process, a capacity to make decisions independently, proper motivation and cooperation with fellow students and the teacher (Shukshina et al., 2017; Vasyakin et al., 2018; Erofeeva et al., 2019a).

Taking into account the above said, we define learner autonomy as "an ability of individuals to consciously carry out their educational activities aimed at creating a personally significant educational product, to selfreflect and adequately evaluate this product, accumulate positive experience, interact constructively and creatively with those participating in educational activities, and take responsibility for the process and result of these activities" (Chernova et al., 2019; Agadzhanova \& Salakhova, 2018; Goloshumova et al., 2019; Grinenko et al., 2019; Mitin et al., 2017).

Today autonomy seems to be gaining additional interest among those working in education. For instance, Umeda (2004) specifies three reasons for the learner autonomy significance: fostering a survival capacity to cope with rapid social changes, developing the learner's individuality, and improving the diversity of the learner's cultural and educational background. According to M. Knowles (1980), one of the key objectives in education is to help learners to get used to the idea of learning as of a process to last a lifetime and to master the skills necessary for independent self-direction on this way.

\section{Russia context}

For the moment Western and Russian scholars have different opinions on the teacher and IHL role in building up learner autonomy. Scholars in the West consider that autonomous learners are primarily responsible for their own learning, and that neither the teacher nor the university is much involved in their learning experience. Nevertheless, to our mind, this approach is unlikely to be used in Russia, since it runs counter to the mentality Russian students.

Some scientists (Hofstede, 1980; Triandis, 1988), addressing different types of culture and cross-cultural psychology have found out that citizens of countries with primarily individualist culture (Europe, the USA), will most likely act as individualists, i.e., independently, autonomously which means that people take care of themselves and are fully responsible for their activities (Goloshumova et al., 2017). His/her top priorities in this culture are personal goals, self-sufficiency, and a possibility to make a choice. Such people are flexible and open-minded. On the contrary, in community-oriented societies (like Russia, former Soviet Republics) from their childhood children are taught to respect communities they belong to. In community-oriented 
cultures employees expect that the organization will take care of them and protect their interests. In those countries management has traditional views on the forms to support activities of the subordinates that may, in our opinion, discourage or limit the development of learner autonomy.

However, we totally agree with D. Nunan (2000), who contends that learner autonomy is not a question of all-or-nothing, that all learners could be trained to develop a degree of autonomy, but that this is a gradual, piecemeal process, the benefit of which we often only see towards the end of the learning process.

So, in the process of building learner autonomy, it is necessary to bear in mind that for centuries the subordination and authority of the teacher's opinion have been covered by and rooted in the Russian system of education. Consequently, in our opinion, the process of forming learner autonomy in university students as parties to the learning activities should gradually proceed with the teacher's participation and take into account all specific aspects of formal education. By formal education we mean the educational process organization meeting five basic requirements: 1) in specialized institutions; 2) by trained personnel; 3) resulting in a generally recognized education certificate; 4) systematic; 5) characterized by the purposeful activity of the students.

As N. Aoki (2008) points out, not every learner is born with autonomy; therefore, fostering autonomy in learners is the teacher's task.

\section{Teacher autonomy}

The issue of teacher autonomy has been in the focus of scholars attention both in Europe and the USA for more than three decades (Allwright, 1990; Benson, 2001; Little, 1994, 1995; Voller, 1997) and is becoming one of the most important educational issues in Russia, particularly in foreign language teaching (Tambovkina, 2007; Koryakovtseva, 2001). Over the last few years, a number of scientists have stressed that the concept of teacher autonomy has been an integral part of the learner autonomy as a whole (Benson, 2001; Little, 1995). Some researchers point out that autonomy is vital for teachers to consider themselves professionals (Ingersoll \& Alsalam, 1997; Pearson \& Moomaw, 2005).

For N.Y. Tambovkina teacher autonomy is "an ability to think and act in one's profession independently; to make one's own choice and important decisions through creating one's own goals and working out individual strategies for meeting these goals" (Tambovkina, 2007: 63).

This philosophy coincides with the ideas of those Russian researchers who believe that teacher autonomy involves responsibility along with mindfulness (Tambovkina, 2007; Leontiev, 2006). Lately some works on teacher autonomy, although not numerous, have been published in Russia, which elucidate this phenomenon in the context of teacher personal development. For instance, G.P. Sharapkina (2004) says that teacher autonomy is fundamental for professional communication and believes that its formation is the highest priority in teacher training process. (Sharapkina, 2004). In N.F. Koryakovtseva's (2001) point of view, autonomy is a must for effective teacher personal development.

On the whole, most definitions of teacher autonomy proposed by Western and Russian scholars have one thing in common, that is an opportunity to be self-governed which means that teachers are given broader powers and freedom in their work and can direct their professional development independently. 
The authors of the article fully share D. Little's (1995) point of view that one cannot await those teachers will be able to develop autonomy in their students if they themselves have no experience of being autonomous learners.

\section{EIEE}

In order to organize the process of developing learner autonomy, in our study - regarding translators in the field of professional communication, modern universities are to effectively use e-learning resources to attain the goals of electronic education, namely: developing the student's personality, implementing the social procurement of modern society taking into consideration electronic communication development, globalization and mass communication; intensifying all educational process levels. At the moment Russia is in need of creating an EIEE at universities, which will help increase the efficiency of higher education based on its individualization and intensification with the aim of developing each student's ability of constant selfimprovement; expanding opportunities for personal and professional growth; creating effective conditions for the development of students' motivation, building up their value-based attitude to the subjects being studied and qualifying for life in the conditions of the information society; fostering skills of productive learning selforganization (Chernova et al., 2019).

By EIEE, we, following I.B. Gosudarev (2016), mean a system that meets the following criteria: 1) comprises EER (electronic educational resources), 2) provides the environment to get access to the educational material, along with the language and electronic tools for managing EER.

The EIEE initial conditions are set up if: 1) educational material is available in the form of EER, and EER are a part of some LMS, 2) linguistic means for communication in the LMS and their development have been identified.

The LMS is an electronic platform on the Internet, designed for posting educational material online and providing communication between teachers and students, and among students themselves (Goloshumova \& Chernova, 2017).

LMSs allow to computerize various administrative objectives, including user administration and interaction, provision of educational material, control of the educational process, paperwork. To make the best choice of the LMS, it is necessary to be aware of their typology, functionality, strengths and weaknesses, guided by the goals of the educational process, teachers and students skills and capabilities to work_with e-learning resources (Chernova et al., 2019).

Whereas the use of various LMSs has been actively discussed both in Russia and abroad (Ryan et al., 2014; Maier \& Warren, 2015; Salmon, 2016), in particular the LMS MOODLE use has been elucidated as applied to teaching foreign languages in linguistic (T.A. Degil, A.Y. Savina) and non-linguistic universities (T.A. Baklashova, M.D. Daricheva). Unfortunately, we have to admit that Russian IHL professors still fall behind their western counterparts.

Taking this fact into account along with a number of specific features of the Russian educational system, its traditions and learning styles, the role of the teacher in the said process, this research focuses on examining the pedagogical conditions necessary to train teachers to take full advantage of the EIEE at IHLs to develop learner autonomy along with the factors that influence this process, challenges the teachers face, components of the teacher's readiness to work in the EIEE. 
The research questions are as follows:

1. What factors hinder a wider use of the EIEE in Russian IHLs to develop learner autonomy?

2. What pedagogical conditions should be provided for teachers to make the EIEE application more extensive?

3. What components make up the teacher's readiness to work in the EIEE and what are their characteristics?

\section{RESEARCH METHOD}

\section{Participants}

The research used the data collected by the Foreign Languages Departments of the Economics Faculty and the Academy of Engineering at RUDN University, the Foreign and Russian Philology Department of Moscow State University of Psychology and Education (MSUPE), as well as the Foreign Languages Department of Moscow State Pedagogical University (MSPU). The dataset consisted of questionnaires, which were filled in by $60 \mathrm{FL}$ teachers. Of the participants, $40(66.7 \%)$ were professors at RUDN University with the EIEE being actively implemented, $10(16.6 \%)$ represented MSUPE and 10 more (16.6\%) were from MSPU. Five respondents (8.3\%) were male and $54(91.7 \%)$ were female. A majority of the respondents (83.3\%) are PhDs. All the participants $(100 \%)$ have been teaching foreign languages for more than five years.

\section{Data collection method}

The questionnaire for the dataset is drawn up by E.Y. Grabko (2015) and modified by the authors in accordance with the aim of the study. To formulate the components of FL teacher's readiness to work in the EIEE, we used the criteria suggested by V.I. Baidenko, I.A. Zimnyaya, and A.V. Khutorskoy (cited by Grabko, 2015). The questionnaire consists of two sections: the former asked for general information about the participants - gender, work experience, academic degree, position. The latter section was focused on their motivation to work in the EIEE and improve their skills in ITs, their interest in self-development. It also included more practical things (technological and cognitive parts of FL teachers readiness) such as knowledge of different methods and techniques necessary to use ITs in professional activities, how much of an idea they have of LMSs and their advantages and disadvantages, factors that can limit the LMS use in Russian universities, ability to assess the quality of e-learning, etc. (see Table 4 for sample questions). As to the items on motivation, the authors adopted the methodology by Milman modified by T.D. Dubovitskaya (cited by Kozlov, Manuilov \& Fetiskin, 2002) along with the techniques described by R.S. Nemov (2001). As to technological and cognitive aspects of FL teacher's readiness, the authors devised the items based on the Standards approved in the Russian Federation, which require particular technical skills of the academic staff at universities. All questionnaire items were presented in Russian and used a three-point scale.

\section{Data analysis}

For comprehensive assessment of the FL teacher's actual readiness to work in the EIEE, we used the Delphi procedure. This research uses the following quantitative data: 1 - low level, 2 - medium level, 3 - high level (see Table 2). Wee calculated the total sum of all indicators as to the FL teacher's readiness to work in the EIEE. To choose the intervals when defining the level boarders of all the components, the authors of this research used the methodology by B.P. Bespal'ko (1989) (see Table 3). This method implies that any activity is considered to be mastered if at least $70 \%$ of all the tasks are done correctly. Low and medium levels are determined by a $25 \%$ assessment deviation from the mean value of points.

We calculated the total characteristics of motivational, cognitive and technological components of FL teacher's readiness using the formula: 


$$
\frac{\sum_{i=1}^{n} K_{i}}{n * N} * 100 \%
$$

Where $\mathrm{K}$ - the number of answers to each question,

$\mathrm{I}$ - the number of the question,

$\mathrm{n}$ - the number of questions,

$\mathrm{N}$ - the number of respondents.

The data analysis shows that FL university teachers in Russia are mostly motivated to work in the EIEE; yet it reveals their low awareness and competence in the methods and techniques along with poor standards of material and technical resources capability.

\section{RESULTS AND DISCUSSION}

Factors that hinder a wider use of the EIEE in Russian IHLS to develop learner autonomy

After analysing the questionnaires, the authors have found out that in the Russian IHL the following factors can be of no small concern to a wider EIEE implementation:

1) Limited (incomplete) preliminary knowledge of foreign language teachers in ITs;

2) Insufficient provision of material and technical resources for FL teachers;

3) Inadequate preparedness level of FL teachers to make use of the new IT in the educational process;

4) Low level of FL teacher's motivation to apply new IT in their work.

Some of the respondents (8.3\%) noted that they didn't have enough time to develop a course in the EIEE because of a heavy load of paperwork.

To resolve the above-mentioned problems, the authors had to work out theoretical and methodological approaches to facilitate the process of developing FL teacher's preparedness to use new information and communication technologies and determine the content of FL teachers training to work in the EIEE. We had to define the concept of FL teachers preparedness to use information and communication technologies, find out and experimentally prove pedagogical conditions to be created in IHLs for FL teachers to achieve a more extensive EIEE implementation and determine the components of FL teachers preparedness to use new information and communication technologies and levels of their IT competence.

Pedagogical conditions to be provided for FL teachers to make the EIEE Application more extensive FL teachers preparedness to use new information and communication technologies is a goal-oriented continuous process to acquire new professional knowledge and skills in applying ITs (including e-learning), constantly developing the IHL EIEE in accordance with the aim to build professional competencies of FL teachers to boost their readiness for Its implementing.

Within the scope of this research at RUDN University we have proved that the following pedagogical conditions are to be provided in IHLs for FL teachers to make the EIEE application more extensive : 1) gradual development of FL teachers readiness to use the EIEE (developing the basic IT - competence on the LMS basis; development of readiness of FL teachers to work in the EIEE through their modular courses); 2) establishing the EIEE in IHLs, which can translate all e-learning possibilities (the LMS, software and documentation among them) into action. Setting up the EIEE in IHLs has to be based on the following principles: 1) adherence to the international trends of e-learning development; 2) the EIEE should be open (in this case any university department will be able to integrate its teaching and learning activities into a 
general system of education); 3) the IHL provides fast and easy access to its electronic resources; 4) compliance with the $\mathrm{IHL}$ requirements as far as the quality of education is concerned; 5) financial and material resource saving; 6) respecting copyright.

\section{Components making up the teachers readiness to work in the EIEE and their characteristics}

FL teachers readiness to work in the EIEE involves integrative professional and personal characteristics, including the need to work in the EIEE to enhance the educational process, to raise self-education motivation using ITs and the EIEE; to improve skills necessary for the proper and competent use of ITs in their work. According to V.I. Baidenko, I.A. Zimnyaya, A.V. Khutorskoy, FL teachers readiness to work in the EIEE embraces the components that follow: motivational, cognitive, and technological. There are three levels of their IT competence: high, medium, and low (Table 1).

Table 1. Components and levels of FL teacher's readiness to use the EIEE.

\begin{tabular}{|c|c|c|c|}
\hline \multirow[b]{3}{*}{ Indicators } & \multirow{2}{*}{\multicolumn{3}{|c|}{$\begin{array}{c}\text { Components of professional readiness } \\
\text { Motivational }\end{array}$}} \\
\hline & & & \\
\hline & High level & Medium level & Low level \\
\hline Participation in the IHL EIEE development & developed & partly developed & undeveloped \\
\hline New ITs integration in the IHL educational process & developed & partly developed & undeveloped \\
\hline $\begin{array}{l}\text { Teachers desire to create and integrate new approaches } \\
\text { and methods into the existing ones }\end{array}$ & developed & partly developed & undeveloped \\
\hline Application of the IHL EIEE potential & developed & partly developed & undeveloped \\
\hline $\begin{array}{l}\text { Meaningful involvement in scientific contests and research, } \\
\text { conferences, workshops, aimed at the active use of ITs }\end{array}$ & developed & partly developed & undeveloped \\
\hline $\begin{array}{l}\text { Interest in additional } \mathrm{HL} \text { rector financial support to } \\
\text { integrate new ITs in educational process }\end{array}$ & developed & ad hoc & undeveloped \\
\hline \multirow{3}{*}{$\begin{array}{l}\text { Readiness to constantly develop oneself as a professional } \\
\text { quality in one's activity }\end{array}$} & developed & ad hoc & undeveloped \\
\hline & \multicolumn{3}{|c|}{ Cognitive } \\
\hline & High level & Medium level & Low level \\
\hline $\begin{array}{l}\text { Awareness of techniques, methods and tools for the } \\
\text { effective use of the EIEE in professional activity }\end{array}$ & developed & partly developed & undeveloped \\
\hline $\begin{array}{l}\text { Comprehension of the EIEE role and importance in } \\
\text { teaching process }\end{array}$ & developed & partly developed & undeveloped \\
\hline \multirow{3}{*}{$\begin{array}{l}\text { Knowledge of different LMSs types, their main advantages } \\
\text { and disadvantages }\end{array}$} & developed & developed & Ad hoc \\
\hline & \multicolumn{3}{|c|}{ Technological } \\
\hline & High level & Medium level & Low level \\
\hline Ability to work in the EIEE & developed & ad hoc & undeveloped \\
\hline $\begin{array}{l}\text { Ability to use main EIEE possibilities and techniques to } \\
\text { organize group and joint work, different types of control, } \\
\text { educational material visualization, students' work } \\
\text { assessment, consultations and communication }\end{array}$ & developed & partly developed & undeveloped \\
\hline $\begin{array}{l}\text { Apply in practice an ability to create educational materials } \\
\text { by means of the LMS, using different resources and } \\
\text { elements }\end{array}$ & formed & partly formed & unformed \\
\hline $\begin{array}{l}\text { Ability to assess the quality of education by means of the } \\
\text { LMS, make up an individual learning path, reveal and } \\
\text { eliminate drawbacks }\end{array}$ & formed & ad hoc & unformed \\
\hline
\end{tabular}


The process of developing teachers readiness to work in the EIEE means a qualitative transition from a low to a higher level.

Table 2 illustrates the Delphi procedure of assessing FL teachers readiness indicators regarding their work in the EIEE.

Table 2. Delphi procedure of assessing the indicators regarding FL teacher's readiness to work in the EIEE.

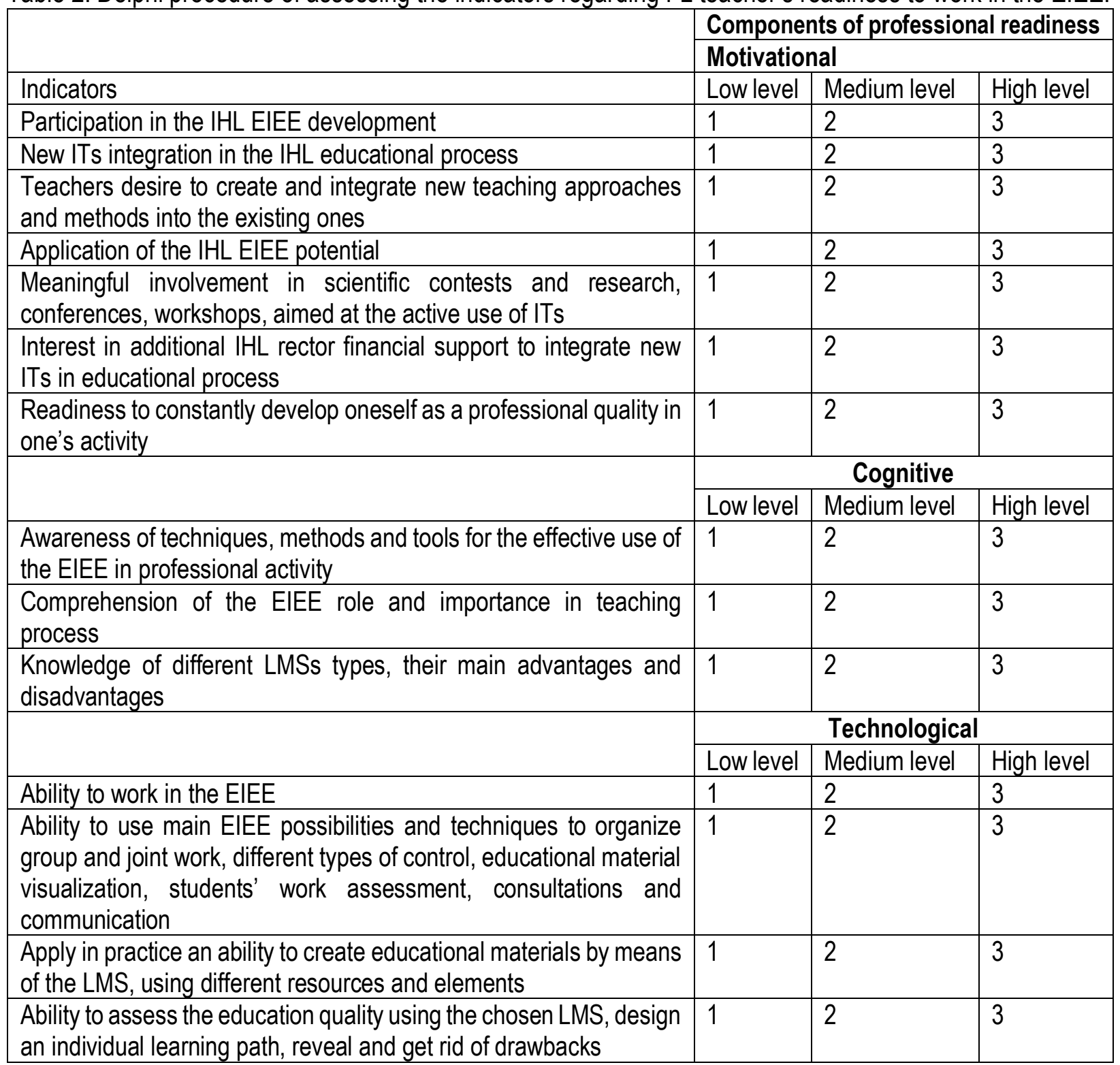

The total sum of all indicators regarding FL teacher's readiness to work in the EIEE can vary from 19 to 57 points.

Table 3 demonstrates the qualitative characteristics of all components level range regarding FL teacher's readiness to work in the EIEE. 
Table 3. Qualitative characteristics of all components level range regarding FL teacher's readiness to work in the EIEE.

\begin{tabular}{|l|c|c|c|}
\hline Level & Low & Medium & High \\
\hline Points & $19-29$ & $30-40$ & $41-57$ \\
\hline
\end{tabular}

Table 4 shows motivational, cognitive and technological components of FL teachers readiness to work in the EIEE.

Table 4. Motivational, cognitive and technological components of FL teacher's readiness to work in the EIEE.

\begin{tabular}{|c|c|c|c|}
\hline Motivational component & Yes & I'm not sure & No \\
\hline $\begin{array}{l}\text { Do you feel a need to improve your ICT-competence, including LMS? } \\
\text { (EIEE) }\end{array}$ & $\begin{array}{l}75 \\
\%\end{array}$ & $25 \%$ & $0 \%$ \\
\hline $\begin{array}{l}\text { Are you interested in acquiring new knowledge as far as LMS is } \\
\text { concerned? (EIEE) }\end{array}$ & $\begin{array}{l}75 \\
\% \\
\end{array}$ & $8.3 \%$ & $\begin{array}{c}16.7 \\
\%\end{array}$ \\
\hline Would you like to use LMS (EIEE) in your professional activities? & $\begin{array}{l}66 . \\
7 \%\end{array}$ & $25 \%$ & $8.3 \%$ \\
\hline Are you interested in creating your own courses in LMS? & $\begin{array}{l}33 . \\
3 \%\end{array}$ & $66.7 \%$ & $0 \%$ \\
\hline $\begin{array}{l}\text { Would you like to get additional financial support for integration of LMS into } \\
\text { the teaching process? }\end{array}$ & $\begin{array}{l}75 \\
\%\end{array}$ & $16.7 \%$ & $8.3 \%$ \\
\hline \multicolumn{4}{|l|}{ Cognitive component } \\
\hline $\begin{array}{l}\text { Do you know methods and techniques necessary to use ITs in professional } \\
\text { activities? }\end{array}$ & $0 \%$ & $91.7 \%$ & $8.3 \%$ \\
\hline $\begin{array}{l}\text { Do you understand the role and significance of using LMS (EIEE) in your } \\
\text { professional activities? }\end{array}$ & $\begin{array}{l}33 . \\
3 \%\end{array}$ & $58.3 \%$ & $8.4 \%$ \\
\hline Do you know the aims of integrating LMS in educational process? & $\begin{array}{l}25 \\
\%\end{array}$ & $58,3 \%$ & $\begin{array}{c}16,7 \\
\%\end{array}$ \\
\hline What main LMSs are you aware of? What are their pros and cons? & $0 \%$ & $75 \%$ & $25 \%$ \\
\hline What educational services can be rendered with LMS in your IHL? & $\begin{array}{l}16 . \\
7 \%\end{array}$ & $66.7 \%$ & $\begin{array}{c}16.6 \\
\%\end{array}$ \\
\hline Do you know the factors that can limit the use of LMS in your IHL? & $\begin{array}{l}41 . \\
7 \%\end{array}$ & $33.3 \%$ & $25 \%$ \\
\hline \multicolumn{4}{|l|}{ Technological component } \\
\hline Can you work in LMS in your IHL? & $\begin{array}{l}50 \\
\%\end{array}$ & $16.7 \%$ & $\begin{array}{c}33.3 \\
\%\end{array}$ \\
\hline $\begin{array}{l}\text { Can you create educational materials by means of LMS with the help of } \\
\text { various resources and elements? }\end{array}$ & $\begin{array}{l}33 . \\
3 \% \\
\end{array}$ & $16.7 \%$ & $50 \%$ \\
\hline Are you capable of evaluating e-learning quality? & $\begin{array}{l}25 \\
\%\end{array}$ & $41.7 \%$ & $\begin{array}{c}33.3 \\
\%\end{array}$ \\
\hline $\begin{array}{l}\text { Are you able to apply different ITs in your work, such as e-mail, } \\
\text { videoconferencing, electronic textbooks, virtual labs? }\end{array}$ & $\begin{array}{l}83 . \\
3 \% \\
\end{array}$ & $16.7 \%$ & $0 \%$ \\
\hline Can you organize intermediary and final control by means of LMS? & $\begin{array}{l}41 . \\
7 \%\end{array}$ & $50 \%$ & $8.3 \%$ \\
\hline
\end{tabular}

Consolidated absolute and relative mean values of motivational, cognitive and technological components regarding FL teachers readiness to work in the EIEE are shown in Table 5. 
Table 5. Consolidated absolute and relative mean values of motivational, cognitive and technological components regarding FL teachers readiness to work in the EIEE.

\begin{tabular}{|l|c|c|c|c|c|c|}
\hline \multirow{2}{*}{ Components, levels } & \multicolumn{2}{|c|}{ Low } & \multicolumn{2}{c|}{ Medium } & \multicolumn{2}{c|}{ High } \\
\cline { 2 - 7 } & Absolute & Relative & Absolute & Relative & Absolute & Relative \\
\hline Motivational & 0 & $0 \%$ & 15 & $25 \%$ & 45 & $75 \%$ \\
\hline Cognitive & 5 & $8.3 \%$ & 55 & $91.7 \%$ & 0 & $0 \%$ \\
\hline Technological & 15 & $25 \%$ & 15 & $25 \%$ & 30 & $50 \%$ \\
\hline
\end{tabular}

It's worth noting that RUDN University has met both pedagogical conditions, namely, free courses for FL teachers and constant support of the technical staff along with the annual contests for the best course in LMS MOODLE, which contributed to an upgrade in results. Almost $100 \%$ of the academic staff can effectively use the EIEE at the moment.

\section{CONCLUSION}

The present study has elucidated several factors that can become an obstacle on the way of FL teachers wider use of the EIEE in Russian IHLs for the development of learner autonomy. The results indicate that: FL teachers possess limited preliminary knowledge of ITs; they do not have enough training toolkit and technical resources; they aren't fully prepared to integrate new ITs in their work; FL teachers lack motivation to apply new ITs in educational process.

The authors have developed a hypothesis and theoretically proved that the following pedagogical conditions can significantly change the current situation for the better: gradual development of FL teachers readiness to use the EIEE (developing the basic IT - competence on the LMS basis, following the LMS; development of readiness of $\mathrm{FL}$ teachers to work in EIEE via their modular courses); 2) setting up the EIEE in IHLs, which can translate all e-learning possibilities into action, the LMS, software and documentation among them. Following the criteria suggested by V.I. Baidenko, I.A. Zimnyaya, A.V. Khutorskoy, the authors have come to the conclusion that FL teachers readiness to work in the EIEE includes the following components: motivational, cognitive, and technological. There are three levels of their IT competence: high, medium, and low. We used the Delphi procedure to assess the level of FL teacher's readiness to work in the EIEE to reveal that at the initial stage most of the respondents fell within the medium level. Implementing the proposed pedagogical conditions at RUDN University have resulted in a notable level improvement as to the FL teacher's readiness to work in the EIEE.

\section{REFERENCES}

Agadzhanova, E.R. \& Salakhova, V.B. (2018). Values and meanings in the context of modes of human existence: to have or to be. Simbirsk Scientific Journal Vestnik, 3(33), 12-16.

Allwright, D. (1990). Autonomy in Language Pedagogy. Lancaster: University of Lancaster.

Anikina, Zh.S. (2011). Learner autonomy as an integral component of teaching foreign languages in the XXI century. Bulletin of Tomsk State University, 344, 149 - 151.

Aoki, N. (2008). The role of teacher in fostering learner autonomy. Eigo Kyoiki the English teachers' Magazine, 56(12), 10-13.

Apanovich, E.V. (2003). Methodology of forming learner skills to actuate language material: PhD Thesis. Irkutsk: Irkutsk State Linguistic University. 
Baidenko, V.I. (2006). Identification of the combination of IHL graduates competences as a necessary stage of drafting new generation SES of higher education. - Moscow : Research center of problems of training specialists quality. $72 \mathrm{p}$.

Baklashova, T.A. (2013). Virtual learning environment in lingvo-cultural training of students of economics. Theory and practice of social development. №9.

Benson, P. (2001). Teaching and researching autonomy in language learning. Harlow: Pearson Education Limited.

Bespal'ko, B.P. (1989). Components of pedagogical technology. Moscow: Pedagogika.

Bezukladnikov, K.E., Kruze, B.A., Vahrusheva, O.V. (2018). Teaching foreign languages to cadets of military school in self-organization environment. Language and culture. - №41. - P.217-240. https://doi.org/10.17223/19996195/41/14

Chernova, O.E., Litvinov, A.V., Telezhko, I.V. \& Goloshumova, G.S. (2019). Development of learner autonomy in electronic information educational environment in institutes of higher learning. Modern science: topical issues of theory and practice, 4, 90-95.

Daricheva, M.V. (2012). About effective use of LMS MOODLE in teaching foreign languages in nonlinguistic universities. Problems of development of life-long professional education: papers of VI International scientific-practical conference. - N. Novgorod: NSPU named after K. Minin. 240 - 243.

Degil, I.M. (2012). Possibilities of electronic textbook to develop sociocultural students competence in a foreign language. Innovative technologies if vocational education: from competence to culturalcreative paradigm: papers of pan-Russian youth conference (Tomsk, 20-22 august, 2012). 155 159.

Dickinson L. (1987). Self-instruction in language learning. - Cambridge University Press. - 200 p.

Dubovitskyaya, T.D. (2002). Methodology of diagnostics of tendency of learning motivation. Psychological science and education. 2, 42-46.

Efimova, O.I., Grinenko, A.V., Kalinina, N.V., Miroshkin, D.V., Bazhdanova, Y.V., Oshchepkov, A.A. \& Ivleva, S.A. (2019). Personality Hardiness as a Factor Determining the Interaction of a Person with the Environment (Psychological and Ecological Aspects). Ekoloji, 107, 563-569, e107063.

Erofeeva, M.A., Grinenko, A.V., Stanovova, L.A., Kosolapova, N.V., Mikhaylovsky, M.N., Rybina, I.A. \& Kochetkov, I.G. (2019c). Motivation and motives of juvenile delinquents. Eurasian Journal of Biosciences, 13(1), p135-140.

Erofeeva, M.A., Stolyarova, A.N., Evseeva, I.G., Popova, T.A., Lobzhanidze, A.A., Luchenkova, M.A. \& Kalinin, I.V. (2019a). The development of a safe educational environment at a higher education institution within the framework of the ecopsychological approach. Ekoloji, 28(107), 5089-5093.

Erofeeva, M.A., Ulyanova, I.V., Plakhotnikova, I.V., Kurilyuk, Y.E., Egorov, V.A. \& Kochetkov, I.G. (2019b). Reforming and developing socialization of children with limited abilities (mild intellectual disability). Electron Journal General Medicine, 16(2), em112. https://doi.org/10.29333/ejgm/108598

Galskova, N.D. (2004).The theory of teaching foreign languages: language education and methodology. Moscow: publishing center "Academy". - 336 p.

Goloshumova, G.S. \& Chernova, O.E. (2017). Potential application of e-learning environment MOODLE in training of IHL students. Philological Class, 3(49), 52-58.

Goloshumova, G.S., Albakova, Z.A-M., Marchev, K.V., Kidinov, A.V., Gustova, E.A., Salakhova, V.B. \& Krasheninnikova, N.A. (2019). The interrelation of environmental and social factors and man's mental health. Ekoloji, 28(107), 6013-6016.

Goloshumova, G.S., Chernova, O.E., Timirov, F.F. \& Ezhov, K.S. (2017). Developing student autonomy in $\mathrm{IHL}$ educational environment. Pedagogical education in Russia, 8, 27-32. https://doi.org/10.26170/po17-08-04 
Gosudarev, I.B. (2016).Terminology of electronic informational educational environment. Man and education, 46(1), 122 - 126.

Grabko, E.Y. (2015). Preparing IHL teachers to use distant learning technologies: PhD Thesis. Cheboksary: Chuvash State Pedagogical University named after I.Y. Yakovlev.

Grinenko, A.V., Gegel, L.A., Poleshchuk, I.A., Tutaeva, D.R., Pronina, E.V., Shchukina, T.V., \& Egorova, E.V. (2019). A governing and political orientation in the field of education. Eurasian Journal of Biosciences, 13(1), 149-154.

Hofstede, G. (1980). Culture's consequences. Beverly Hills: Sage.

Holec, H. (1979). Autonomy and Foreign Language Learning. Oxford: Pergamon Press.

Ingersoll, R \& Alsalam, N. (1997). Teacher professionalism and teacher commitment: A multilevel analysis. NCES 97-069, Washington: U.S. Department of Education.

Kalinina, N.V. (2011). Social and personal resources to overcome difficult life situations. Simbirsk Scientific Journal Vestnik, 1(3), 96-101.

Kapaeva, A.E. (2001). On forming learner readiness for self-teaching of foreign languages. Foreign languages at school, 3, 12-17.

Kayumova, L.R., Zakirova, V.G., Sizova, Z.M., \& Buslaev, S.I. (2020). Peculiarities of future teachers' training in professional activities in risk settings: Methods and technologies. Talent Development and Excellence, 12(Special Issue3), 50-63.

Khodyakov, D.A. (2013). Linguo-didactic model of developing learner autonomy of high-school children. Bulletin of Volgograd State Pedagogical University, 80(5), 85 - 89.

Khutorskoy, A.V. (2002). Key competences and educational standards. Aidos.

Knowles, M. (1980). The modern practice of adult education: Andragogy versus pedagogy. New York: Cambridge Adult Education.

Kolesnikova, I.A. (2003) Basics of andragogy. Moscow: Academy.

Koryakovtseva, N.F. (2001). Learner autonomy in learning foreign languages in class activity as educational goal. Foreign language at school, 1, 13-27.

Kozlov, V.V., Manuilov, G.M. \& Fetiskin, N.P. (2002). Social and psychological diagnostics of personality and small groups' development. Moscow: Institute of Behavioral Therapy.

Kulutkin, Y.N. (1985). Psychology for teaching adults. Moscow: Progress.

Lekareva, E.E., Zaretskiy, V.V., Artamonova, E.G., Salakhova, V.B., Efimova, O.I. \& Kalinina, N.V. (2018). Comprehensive rehabilitation of minors with deviant and delinquent behavior: The experience of the Russian system of education. Eurasian journal of analytical chemistry. Eurasian Journal of Analytical Chemistry, 13(1b), em84. https://doi.org/10.29333/ejac/102249

Leontiev, D.A. (2006). Positive Personality Development: Approaching Personal Autonomy. In A Life Worth Living: Contributions to Positive Psychology. New York: Oxford University Press.

Little, D. (1991). Learner Autonomy. Dublin: Authentik.

Little, D. (1994). Autonomous Teacher. Strasbourg: Council of Europe.

Little, D. (1995). Learning as dialogue: The dependence of learner autonomy on teacher autonomy. System, 23(2), 175-81. https://doi.org/10.1016/0346-251X(95)00006-6

Littlewood, W. (1999). Defining and developing autonomy in East Asian contexts. Applied Linguistics, 20, 71-94. https://doi.org/10.1093/applin/20.1.71

Luksha, I.V. (2008) Language laboratory as a means of learner autonomy optimization in multimedia vocationally-oriented context: PhD thesis. Tomsk: Tomsk State Pedagogical University.

Maier, P. \& Warren, A. (2015). Integrating Technology in Learning and Teaching. London: Kogan Page.

Mitin, S.N., Shukshina, L.V., Bazhdanova, Y.V., Koretskaya, I.A. \& Vasyakin, B.S. (2017). Value and meaning attitudes as a factor of forming tolerant ethnic consciousness in the multicultural milieu of a 
higher education institution. Eurasian Journal of Analytical Chemistry, 12(7), 1193-1200. https://doi.org/10.12973/ejac.2017.00244a

Nasonova, E.A. (2008). Teaching vocationally-oriented dialogue communication to students in the conditions of learner autonomy by means of internet-chat: PhD thesis. Volgograd: Volgograd State University.

Nemov, R.S. (2001). Psycology. Psycodiagnostics. Moscow: Vlados.

Nunan, D. (2000). Autonomy in language learning. Cartagena: Pérez-Paredes.

Pearson, L.S. \& Moomaw, W. (2005). The relationship between teacher autonomy and stress, work satisfaction, empowerment, and professionalism. Educational Research Quarterly, 29(1), 38-54

Romanova, A.V., Salakhova, V.B., Ganova, T.V., Nalichaeva, S.A., Nazarova, L.S. \& Dolzhenko, A.I. (2019). Hardiness as a component for sustainable development of a person's personality: Ecological and psychological aspect. EurAsian Journal of BioSciences, 13(2), 1833-1840.

Ryan, S., Scott, B., Freeman, H. \& Patel, D. (2014). The Virtual University: The Internet and Resourcebased Learning. London: Kogan Page. https://doi.org/10.4324/9781315042022

Salmon, G. (2016). E-moderating. The key to teaching and learning online. London: Kogan Page.

Savina, O.Y. (2011). Experience of combined teaching in LMS MOODLE when preparing specialists of "Theory and methodology of teaching German". Problems of linguistics and linguistic education: collection of articles. 227-238.

Sharapkina, G.P. (2004). Teacher autonomy development as a factor of professional socialization". In International scientific-methods symposium (pp.146-148). Pyatigorsk: Pyatigorsk State Linguistic Unoversity.

Shinkevich, M.V., Mashkin, N.A., Ishmuradova, I.I., Kolosova, V.V., \& Popova, O.V. (2020). Management of sustainable consumption of energy resources in the conditions of digital transformation of the industrial complex. International Journal of Energy Economics and Policy, 10(5), 454-460. https://doi.org/10.32479/ijeep.10202

Shukshina, L.V., Bazhdanova, Y.V., Koretskaya, I.A., Vasyakin, B.S. \& Lipatova, N.V. (2017). Development of multicultural value orientations in future specialists in the context of a higher education institution. Eurasian Journal of Analytical Chemistry, 12(5), 775-885. https://doi.org/10.12973/ejac.2017.00217a

Simonyan, K.V. (2008) Methodology of applying computer technologies in the organization of self-guided learning: PhD Thesis. Moscow: Moscow State Linguistic University.

Solovova, E.N. (2004) Learner autonomy as a basis of development of modern life-long personality development. Foreign languages at school. - № 2. - P. 11 - 17.

Tambovkina, T.Y. (2007). Self-guided learning of foreign languages as a subsystem of language education in IHLs: PhD Thesis. Moscow: Russian State University named after I.Kant.

Telysheva, N.N., Erofeeva, M.A., Ulyanova, I.V. Pokrovskaya, S.V., Nikitskaya, E.A., Gorokhova, I.V. \& Kochetkov, I.G. (2019). Socio-Ecological Determinants in the Deviant Behavior Formation System. Ekoloji, 28(107), 5077-5081.

Ternovykh, T.Y. (2007). Methodology of forming strategies of learner autonomy in the work with foreign texts: PhD Thesis. Moscow: Moscow State University.

Triandis, H.C. (1988). Collectivism and individualism: A reconceptualization of a basic concept in crosscultural psychology. In G.K. Verma \& C. Bagley (Eds.). Personality, attitudes, and cognitions (pp. 6095). London: MacMillan. https://doi.org/10.1007/978-1-349-08120-2__3

Trofimova, I.D. (2003). Methodology of forming strategies of autonomous reading of linguistic university students. Candidate thesis, Ulan-Udeh. - 222 p.

Tsvetkova, T.K. (2001) Ways of forming learner autonomy in the educational process when teaching foreign languages. Bulletin of Moscow State Linguistic University, 461, 62 - 72. 
Tsyvkunova, E.A. (2002). Formation of learner autonomy of linguistic university on the basis of interdisciplinary interaction of subjects (Candidate thesis). Moscow: Moscow State Linguistic University.

Umeda, Y. (2004). The teacher's role in Japanese language attaching importance to learner autonomy. Aichi University language and culture, 12.

Ur, P. (1996). A course in language teaching: Practice and theory. Cambridge: Cambridge University Press.

Vasyakin, B.S., Berezhnaya, M.S., Pozharskaya, E.L. \& Ovsyanik, O.A. (2018). Socio-psychological training in modern health psycho-technological toolkit to improve stress tolerance in academic personnel. Teoriya i Praktika Fizicheskoy Kultury, 8, 75-76.

Voller, P. (1997). Does the Teacher Have a Role in Autonomous Learning? In P. Benson \& P. Voller (Eds.). Autonomy and Independence in Language Learning (pp192-203). London: Longman.

Zimnyaya, I.A. (2006). Key competences - a new paradigm of the result of contemporary education. Aidos. 